\title{
Leaf relative chlorophyll content as an indicator parameter to predict nitrogen fertilization in maize
}

\author{
Teor relativo de clorofila na folha como parâmetro indicativo para predição da \\ necessidade de adubação nitrogenada em milho
}

\author{
Gilber Argenta ${ }^{1}$ Paulo Regis Ferreira da Silva ${ }^{2}$ Luis Sangoi $^{3}$
}

\section{ABSTRACT}

The development of a portable chlorophyll meter (SPAD 502), that takes instantaneous measurements of greenness without leaf destruction, has emerged as a new tool to assess plant $N$ status. This trial was carried out to determine the adequate SPAD readings to predict maize nitrogen needs in four growth stages. The experiment was conducted in the state of Rio Grande do Sul, southern Brazil, during the 1998/ 99 growing season. Treatments were two maize hybrids (Pioneer 32R21 and Cargill 901) and nine side-dressed nitrogen levels $(0,50,100,150,200,300,400,500$ and $\left.600 \mathrm{~kg} \mathrm{ha}^{-1}\right)$. Nitrogen was side-dressed at the soil surface in four equal doses, according to the levels established on each treatment. The first, second, third and fourth applications were made in the stages of three to four, six to seven, 10 to 11 and 14 to 15 fully expanded leaves, respectively. Urea was used as the $N$ source. Since there was no difference in the $S P A D$ readings among maize hybrids, average values at each stage were used. Readings were carried out in the stages of three to four, six to seven, 10 to 11 fully expanded leaves and at silking. Chlorophyll evaluation samples were taken at twothirds of the distance from the leaf tip towards the stem. The two upper leaves were sampled on each growth stage before maize flowering. The index leaf (first leaf below the ear) was evaluated during silking. Chlorophyll meter readings above $45.4,52.1,55.3$, and 58.0 represented the adequate values for the stages of three to four, six to seven, 10 to 11 expanded leaves and at silking, respectively, to achieve high grain yield. The variation in SPAD readings were highest in the early stages of plant growth.

Key words: Zea mays, portable chlorophyll meter, adequate nitrogen level.

\section{RESUMO}

O medidor portátil de clorofila SPAD 502, que permite leituras instantâneas da intensidade da cor verde da folha (valor correspondente ao teor de clorofila) sem destruí-la, surgiu como uma alternativa para avaliar o nível de $N$ na planta. Com o objetivo de determinar os valores adequados da leitura SPAD, em quatro estádios de desenvolvimento da planta de milho, conduziu-se um experimento em Eldorado do Sul, RS, no ano agrícola 1998/1999. Os tratamentos constaram de dois híbridos de milho (Pioneer 32R21 $e$ Cargill 901) e de nove níveis de $N(0,50,100,150,200,300,400$, 500 e $600 \mathrm{~kg} \mathrm{ha}^{-1}$ de N). O N foi aplicado em cobertura ao lado da linha de semeadura, em quatro doses iguais, de acordo com o nível estabelecido em cada tratamento. A primeira, segunda, terceira e quarta aplicações foram feitas nos estádios de três a quatro, seis a sete, 10 a 11 e 14 a 15 folhas desenvolvidas. A uréia foi utilizada como fonte de N. Como os valores de leitura SPAD entre as cultivares foram similares, utilizou-se o valor médio em cada estádio avaliado. Para diagnóstico do nível de $\mathrm{N}$ na planta de milho, as leituras no clorofilometro maiores que 45,4, 52,1, 55,3 e 58,0, respectivamente, para os estádios de três a quatro folhas, seis a sete folhas, 10 a 11 folhas e no espigamento, foram considerados adequados para obter altos rendimentos de grãos. A variação na leitura SPAD foi maior nos estádios iniciais de desenvolvimento da cultura do milho.

Palavras-chave: Zea mays L., leitura SPAD, nível adequado de nitrogênio.

\section{INTRODUCTION}

Several methods to predict maize $\mathrm{N}$ needs during vegetative growth stages have already been

${ }^{1}$ This manuscript was extracted from the first author's Thesis in Crop Science.

${ }^{2}$ Engenheiro Agrônomo, Doutor, Desenvolvimento de Produtos Syngenta Seeds Ltda. Av. Bento Gonçalves, 7712, 90001-970, Porto Alegre, RS. Departamento de Plantas de Lavoura. E.mail: gilber.argenta@syngenta.com. Corresponding author.

${ }^{3}$ Engenheiro Agrônomo, Doutor, Professor, Departamento de Plantas de Lavoura da Faculdade de Agronomia, Universidade Federal do Rio Grande do Sul. Bolsista do CNPq. E-mail: paulo.silva@vortex.ufrgs.br

${ }^{4}$ Engenheiro Agrônomo, Doutor, Professor, Departamento de Fitotecnia, Centro de Ciências Agropecuárias, Universidade de Desenvolvimento do Estado de Santa Catarina. Bolsista do CNPq. E-mail: a21s@ravines hr 
tested (FOX et al., 1989; HONG et al., 1990; MAGDOFF et al., 1990, BINFORD et al., 1992, SIMS et al., 1995). They are based on soil tests and lab analyses of tissue samples. They have the advantages of presenting good correlation with grain yield and acceptable level of accuracy. However, they also have the disadvantages of being time consuming, cumbersome and expensive.

The development of a portable chlorophyll meter, that takes instantaneous readings of leaf light interceptance related to greenness and relative chlorophyll content, is an alternative to evaluate maize $\mathrm{N}$ status (ARGENTA, 2001). The relationship between readings of portable chlorophyll meter and leaf chlorophyll content and between leaf chlorophyll content and plant $\mathrm{N}$ content have been demonstrated by several authors (YADAVA, 1986; MARQUARD \& TIPTON, 1987; SMEAL \& ZHANG, 1994; DWYER et al., 1995; ARGENTA et al., 2001c).

Portable chlorophyll measurements have being evaluated in various crops (ARGENTA et al., 2001a). For maize, readings taken with this equipment presented variable correlation with grain yield depending on the plant growth stage. Low correlation values between chlorophyll content and grain yield were obtained during early growth (SMEAL and ZHANG, 1994; WASKOM et al., 1996; BULLOCK and ANDERSON, 1998), probably due to the use of a methodology designed originally for rice and wheat. This methodology creates variability in $\mathrm{N}$ levels applying different nitrogen doses at specific growth stages. Once the variability is generated, no more $\mathrm{N}$ is applied. Differently from rice and wheat, maize has several developmental stages where grain yield is defined. During the stages of three to four fully expanded leaves, the ear row number is defined (SCHREIBER et al., 1988). At the stages of seven to eight and 11 to 12 expanded leaves, the number of ovules per ear and ear size are established (HANWAY, 1963). From two weeks before to three weeks after silking, the number of grains per ear is determined (EARLEY et al., 1967). Therefore, $\mathrm{N}$ deficiency at any particular stage can affect grain yield and its correlation with chlorophyll meter readings. The longer period of grain yield definition presented by maize may create a situation where plants switch from an adequate $\mathrm{N}$ status to a $\mathrm{N}$ deficient tissue content during the crop ontogeny, if no additional nitrogen is applied. Consequently, the crop will adjust to this new scenario reducing grain yield.

In order to get higher correlation between chlorophyll meter readings and maize grain yield, specially in early developmental stages, it is necessary to use a methodology where plants are well supplemented with this nutrient during the whole vegetative cycle. The generation of $\mathrm{N}$ content variability in all the desired growth stages will allow the correct determination of the critical level nitrogen in the leaves.

The correlation between chlorophyll readings and grain yield is higher during later stages of maize development (WOOD et al., 1992; SMEAL and ZHANG, 1994; BLACKMER and SCHEPERS, 1995; SUNDERMAN et al., 1997). However, the diagnosis of $\mathrm{N}$ tissue levels in late stages of plant growth do not allow the correction of nitrogen deficiency in the same growing season.

Therefore, the identification of nutrient deficiency during the beginning of maize life cycle is an important strategy to manage $\mathrm{N}$ wisely because it allows growers to synchronize the crop's nitrogen need with nitrogen availability in the soil. Furthermore, it makes possible to correct $\mathrm{N}$ deficiency in the same growing season. Consequently, the establishment of curves of adequate $\mathrm{N}$ content during initial stages of maize growth is a promising alternative in order to make accurate decisions on $\mathrm{N}$ management.

ARGENTA et al. (2001b) tested some plant parameters ( $\mathrm{N}$ content and accumulation, chlorophyll content assessed with a portable chlorophyll meter, dry matter and leaf area) as indicators of maize $\mathrm{N}$ content. They verified that the portable chlorophyll meter reading estimated with good accuracy the relative chlorophyll content in maize leaf, being also the most accurate parameter to estimate the plant $\mathrm{N}$ level (ARGENTA et al., 2002; ARGENTA et al., 2001c).

This work aimed to determine the nitrogen adequate content of maize tissue in four growth stages based on readings taken with a portable chlorophyll meter, and to establish the adequate $\mathrm{N}$ content for maize developmental stages.

\section{MATERIAL AND METHODS}

A field experiment was conducted during the growing season of 1998/99 at the Agronomy Experimental Station of Universidade Federal do Rio Grande do Sul, located in the city of Eldorado do Sul, Southern Brazil. According to Köppen, the climate of the region is classified as subtropical humid, located in the transition between the basic types cfa1 (annual isothermal lower than $18^{\circ} \mathrm{C}$ ) and cfa2 (annual isothermal higher than $18{ }^{\circ} \mathrm{C}$ ) (MORENO, 1961). The annual maximum and minimum temperature averages are 19.6, 24.3 and $14.8^{\circ} \mathrm{C}$, respectively (IPAGRO, 1989). The soil is classified as Red Argissolo Typical Distrofic 
(EMBRAPA, 1999) and presented the following composition: clay: $280 \mathrm{~g} \mathrm{dm}^{-3}, \mathrm{pH}$ (in water): 5.2; phosphorus, potassium and organic matter contents of $16 \mathrm{mg} \mathrm{dm}^{-3}, 134 \mathrm{mg} \mathrm{dm}^{-3}$ and $2.6 \mathrm{mg} \mathrm{dm}^{-3}$, respectively. The experimental area has been cultivated in no tillage system for four years, using black oats as the winter crop from 1994 to 1997. Common vetch (Vicia sativa) was grown in the winter of 1998. Maize, soybean, maize and maize were established as summer crops during the growing seasons of 1994/95, 1995/96, 1996/97 and 1997/98, respectively.

Two short season simple hybrids (Pioneer 32R21 and Cargill 901) and nine side-dressed nitrogen levels $\left(0,50,100,150,200,300,400,500\right.$ and $600 \mathrm{~kg} \mathrm{ha}^{-}$ ${ }^{1}$ of $\mathrm{N}$ ) were tested. Quantities of $30 \mathrm{~kg} \mathrm{ha}^{-1}$ of N, 120 $\mathrm{kg} \mathrm{ha}^{-1}$ of $\mathrm{P}_{2} \mathrm{O}_{5}$ and $120 \mathrm{~kg} \mathrm{ha}^{-1}$ of $\mathrm{K}_{2} \mathrm{O}$ were banded in the rows at maize sowing. Nitrogen application was side-dressed at the soil surface in four equal doses, according to the levels established on each treatment. The first, second, third and fourth application were done in the stages of three to four, six to seven, 10 to 11 and 14 to 15 fully expanded leaves. Urea was used as $\mathrm{N}$ source.

Corn hybrids were hand planted on October $9^{\text {th }}, 1998$. A row spacing of $0.7 \mathrm{~m}$ and a plant density of 65.000 plants ha ${ }^{-1}$ were used. Eigth rows per plot were used. Rows were $6.0 \mathrm{~m}$ long. A split-plot design with the main plots arranged in randomized complete blocks was used. Hybrids were located in the main plots and $\mathrm{N}$ levels in the split-plots. Treatments were replicated four times.

Grain yield and the corresponding readings of chlorophyll content taken with a portable chlorophyll meter were determined. Chlorophyll meter readings were made using Minolta SPAD 502 chlorophyll meter. Grain yield was calculated per hectare in a standard moisture of $130 \mathrm{~g} \mathrm{~kg}^{-1}$. Readings with portable chlorophyll meter were carried out in the stages of three to four, six to seven, 10 to 11 leaves fully expanded leaves and at silking. SPAD readings were taken at two-thirds of the distance from the leaf tip towards the stem. The two upper leaves were sampled on each growth stage before maize flowering. At the silking stage, the reading was done at the index leaf (first leaf below the ear). Five plants per split plot were measured on each sampling time.

Statistical analysis was performed using the Statistical Analysis System (SAS Institute, 1992). A regression analysis between the readings of portable chlorophyll meter (SPAD) as dependent variable and grain yield was carried out for each hybrid in order to determine the SPAD reading values that represented the adequate tissue $\mathrm{N}$ content for each evaluated growth stage. The third, sixth, ninth and the index leaves were used as leaf standards for the stages of three to four, six to seven, 10 to 11 fully expanded leaves and silking, respectively, following procedure presented by ARGENTA et al. (2001b). Whenever the $F$ test of the regression between the two variables was not significant, the reading values that represented adequate SPAD index were obtained computing the average of the readings minus the standard deviation of the average, in order to avoid the overestimation of SPAD reading values. For the growth stages where the quadratic regression was significant, adequate reading values were calculated deriving the regression equation and subtracting the standard deviation of the average, following methodology adapted of WASKOM et al. (1996). Optimum chlorophyll meter reading was defined by these authors as the mean of all treatments, one $\mathrm{N}$ increment $\left(45 \mathrm{~kg} \mathrm{ha}^{-1}\right)$ above the yield plateau.

The Cate-Nelson's graph (CATE \& NELSON, 1987), modified by PIEKIELEK et al. (1995), was used to group treatments with $\mathrm{N}$ deficiency and adequate contents of the N. SPAD reading was $\mathrm{X}$-axis and relative grain yield was $\mathrm{Y}$-axis. The relative grain yield was calculated dividing individual treatment's grain yield by the average grain yield of those treatments that did not differ statistically from each other. The relative grain yield of 0.92 , suggested by PIEKIELEK and FOX (1992), was used as the critical level in the horizontal line. The portable chlorophyll meter reading values determined on each growth stage were employed as the critical levels in the vertical line. Data located in the upper right and lower left quadrants corresponded to treatments with $\mathrm{N}$ deficiency and $\mathrm{N}$ adequate content, respectively. Data positioned in the lower right and upper left quadrants represented errors of overestimation and underestimation of the plant $\mathrm{N}$ level, respectively.

\section{RESULTS AND DISCUSSION}

The regressions between SPAD readings and maize grain yield were not significant for both hybrids in the stages of three to four and six to seven fully expanded leaves (Figures 1A, 1B, 1C and 1D). These results suggest that there was no $\mathrm{N}$ restriction during early stages of maize development as shown by WASKOM et al. (1996), probably due to the high $\mathrm{N}$ contribution from the preceding crop's residue (common vetch), or to the $30 \mathrm{~kg} \mathrm{ha}^{-1}$ nitrogen row fertilization at sowing. The SPAD reading values corresponding to the adequate $\mathrm{N}$ level in the tissue were $45.4(47.2 \pm 1.8)$ and $52.1(54,1 \pm 2.0)$, for the 

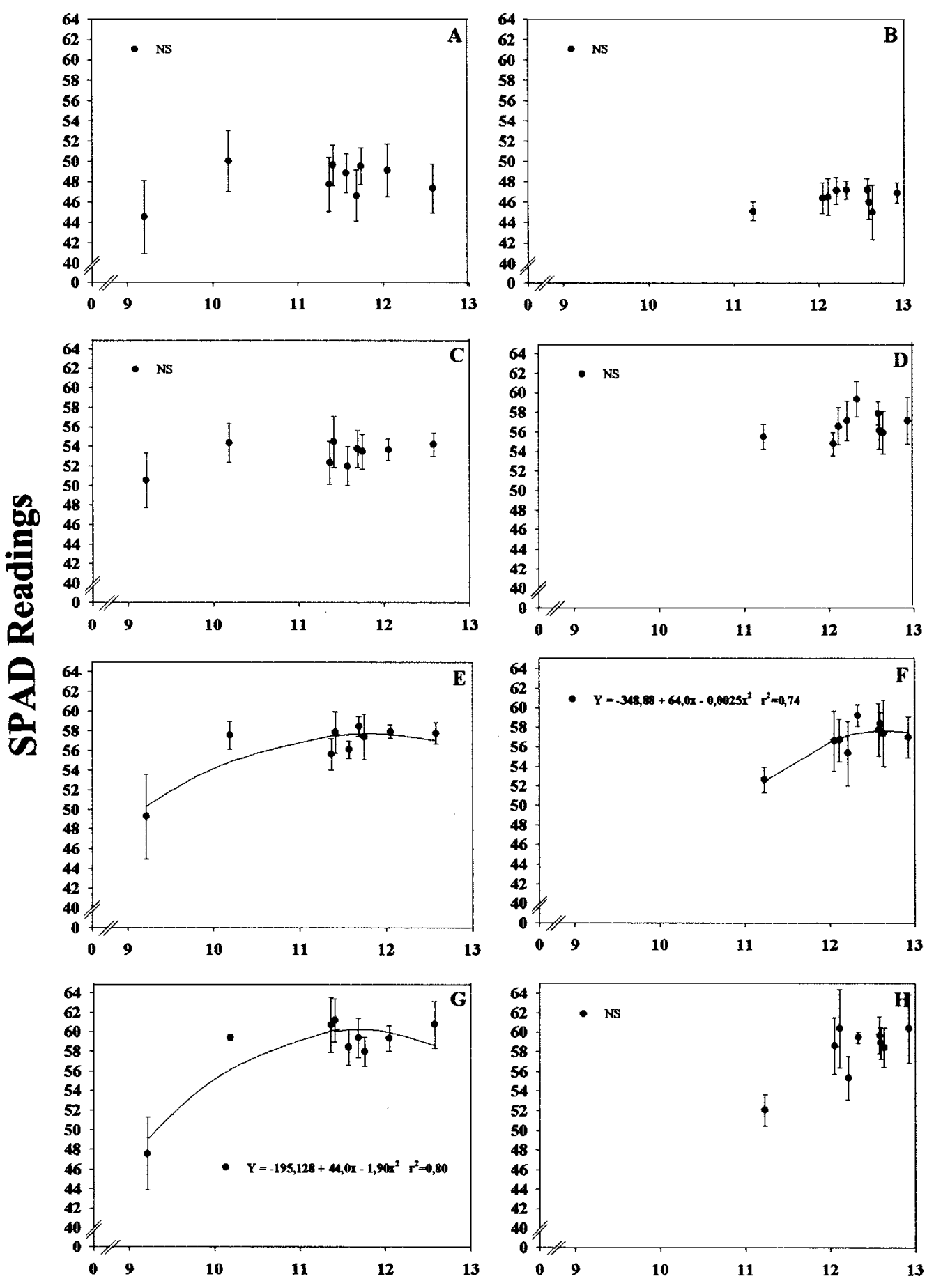

\section{Grain Yield - Mg.ha-1}

Figure 1 - Relationship between readings of the portable chlorophyll meter (SPAD) at the V3 stage in the third leaf (A and B), V6 in the sixth leaf $(C$ and $D), V 10$ in the nineth leaf $(E$ and $F)$ and at silking at the index leaf $(\mathrm{G}$ and $\mathrm{H})$ and grain yield of maize hybrids Pioneer 32R21 (A, C, E and G) and Cargill 901 (B, D, F and H). Rio Grande do Sul, Brazil, 1998/99. Vertical bars represent average standard deviation.

Ciência Rural, v.34, n.5, set-out, 2004. 
stages of three to four and six to seven fully expanded leaves. The last value was higher than 42.0 and 43.4 obtained by JEMISON \& LYTLE (1996) and PIEKIELEK \& FOX (1992), respectively. These authors estimated critical values sampling the fifth leaf without applying nitrogen, while in the present work readings were taken in the sixth leaf in plots with $\mathrm{N}$ application.

The regressions between SPAD readings and grain yield were significant for both hybrids in the stage of 10 to 11 fully expanded leaves (Figures 1E and $1 \mathrm{~F})$. The estimated points of maximum SPAD readings were 57.6 and 57.3 for hybrids Pioneer 32R 21 and Cargill 901, respectively. Since these values were very close, the SPAD reading that indicate adequate $\mathrm{N}$ level was calculated considering the hybrids average value minus the standard deviation of the average (2.2). The estimated reading for this growth stage (55.3) was higher than the values of 51.2 and $48.6 \pm 3.8$ determined by WASKOM et al. (1996) and SUNDERMAN et al. (1997), respectively. The lower SPAD reading values reported by these authors can be attributed mainly to the different methodologies used to estimate adequate $\mathrm{N}$ level. Our values were obtained through the derivation of the equation, whereas the previously mentioned author's values were estimated by the average of tested hybrids. Furthermore, differences in inherent chlorophyll content of tested hybrids can partially account for the different SPAD values reported in the literature. The genetic load of hybrids evaluated in our trial is mostly subtropical whereas WASKOM et al. (1996) and SUNDERMAN et al. (1997) tested temperate climate materials. Diversity in genetic background may interfere on $\mathrm{N}$ metabolism, causing variations in leaf chlorophyll content (SCHEPERS et al., 1992).

At the silking stage, the regression between SPAD readings and grain yield was significant only for hybrid Pioneer 32R21 (Figures $1 \mathrm{G}$ and $1 \mathrm{H}$ ). The estimated point of maximum SPAD reading for this hybrid was 60.0. The standard deviation of the average was 2.0, leading to an adequate $\mathrm{N}$ value correspondent to a SPAD reading of 58.0. A similar number was found by SUNDERMAN et al. (1997) who determined the SPAD reading of $57.9 \pm 4.5$ at the beginning of silking.

The modified Cate-Nelson graph showed that SPAD reading values estimated to indicate the adequate $\mathrm{N}$ level were accurate to group treatments with nitrogen deficiency and satisfactory levels, at all growth stages evaluated in the trial (Figure 2). Considering the two hybrids average, SPAD reading values representing the $\mathrm{N}$ adequate level estimated accurately maize grain yield in $83,89,89$ and $83 \%$ of the treatments, in the stages of three to four, six to seven, 10 to 11 fully expanded leaves and at silking, respectively. These high percentages indicate a small error of overestimation and underestimation of the plant $\mathrm{N}$ content.

Several factors besides $\mathrm{N}$ availability in the soil can affect chlorophyll synthesis, interfering with the measurements of leaf greenness index by chlorophyll meters. Among them, the literature has emphasized: hybrids (SUNDERMAN et al., 1997), cultivation site (SMEAL \& ZHANG, 1994; WASKOM et al., 1996), levels of other nutrients (AL-ABBAS et al., 1974; MASONI et al., 1996), light availability (THOMAS \& STODDART, 1980), presence of insects (SMEAL \& ZHANG, 1994), water stress (SCHEPERS et al., 1992), air temperature (DWYER et al., 1995), crop growth speed (SMEAL \& ZHANG, 1994), plant density (HASHEMI-DEZFOULI \& HERBERT, 1992), and herbicide use (MAYASICH et al., 1990).

In order to correct the influence of those factors on chlorophyll concentration and assess accurately the leaf greenness index of maize in the field, SPAD readings need to have a reference strip of plants of the same cultivar, grown in a well fertilized area, at the same farming site. Whenever the relative percentage of chlorophyll determined in a particular spot is below $95 \%$ of the reference strip, the use of additional $\mathrm{N}$ fertilizer is suggested (BLACKMER \& SCHEPERS, 1995; PIEKIELEK et al., 1995; WASKOM et al., 1996; JEMISON \& LYTLE, 1996; VARVEL et al., 1997). However, the SPAD reading values estimated herein to indicate adequate $\mathrm{N}$ level can replace, in part, this reference strip, correcting the influence of other factors on chlorophyll content, regardless of maize growth stage. This inference relies on the fact that the SPAD reading values were obtained under high management level where the previously reported factors that could affect chlorophyll synthesis were controlled. Furthermore, possible differences in reading values due to genotype variation can be removed, specially in vegetative stages, if the determination is carried out in plants at the same growth stage (SUNDERMAN et al., 1997).

SPAD reading values increased quadratically as maize growth and development proceeded from three expanded leaves towards silking (Figure 3). The calculated equation allows growers to estimate chlorophyll reading values representative of adequate tissue nitrogen supply at growth stages not determined in the present experiment. A quadratic enhancement in portable chlorophyll reading values with crop development has also been detected by SUNDERMAN et al. (1997). The apparent lower leaf chlorophyll content registered during early 

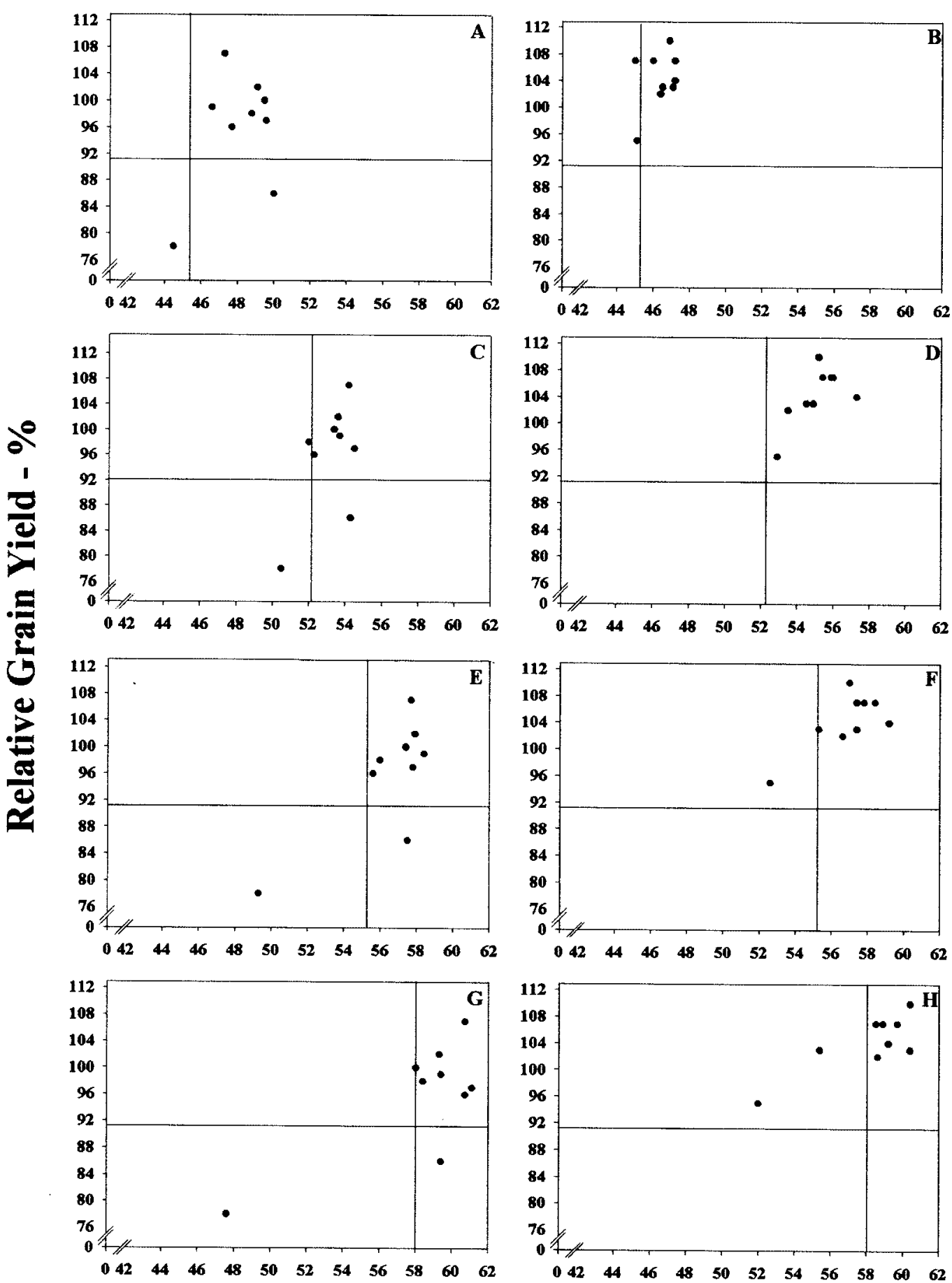

SPAD Readings

Figure 2 - Maize relative grain yield in relation to the average grain yield of treatments that had not differentiated in function of reading in the portable chlorophyll meter at the V3 stage in the third leaf (A and B), V6 in the sixth leaf (C and D), V10 in the nineth leaf (E and F) and a silking in the index leaf ( $\mathrm{G}$ and $\mathrm{H})$ and grain yield of maize hybrids Pioneer 32R21 (A, C, E and G) and Cargill 901 (B, D, F and H). Rio Grande do Sul, Brazil, 1998/99.

Ciência Rural, v.34, n.5, set-out, 2004. 


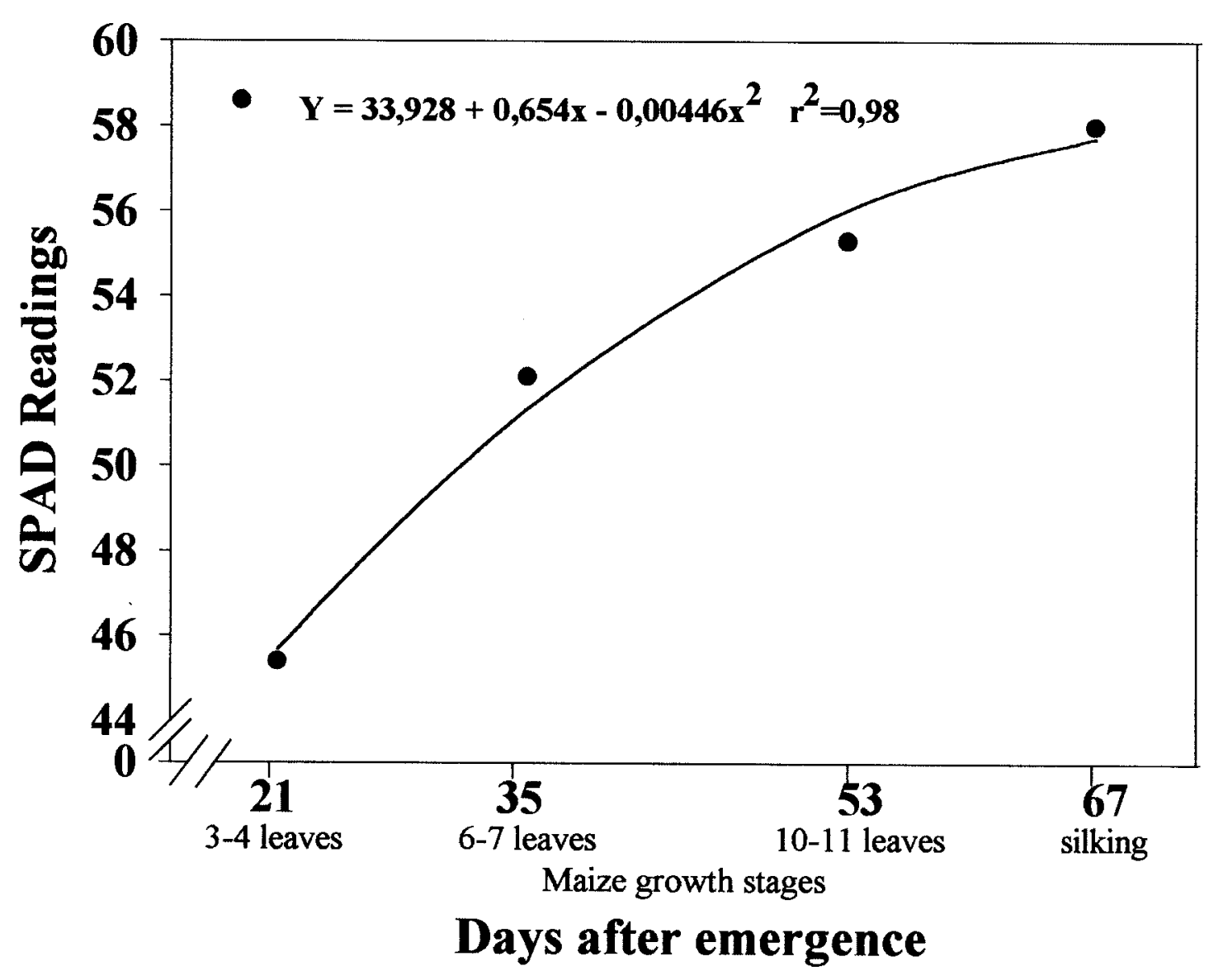

Figure 3 - Readings in the portable chlorophyll meter (SPAD) as a function of maize growth stages. Rio Grande do Sul, Brazil, $1998 / 99$.

developmental stages and the quadratic increase in SPAD reading values from three expanded leaves to silking indicate that a high part of the absorbed $\mathrm{N}$ was used to produce other plant structures rather than chlorophyll early in the crop's ontogeny. Since the amount of nitrate present in plant tissue was very low (data not presented), we speculate that nitrogen taken up by maize during early growth stages is used primarily to the formation and expansion of leaves and stems. A fast establishment of such structures is instrumental to enhance light interception, leading to an increase in radiation use efficiency and grain yield (SALISBURY \& ROSS, 1992; MARSCHNER, 1995).

The variation of SPAD reading values was high in early stages of maize development (from threefour to six-seven fully expanded leaves), averaging 0.48 units day $^{-1}$. Conversely, SPAD reading values varied only 0.18 and 0.19 units day $^{-1}$ from the stages of six-seven to 10-11 and 10-11 fully expanded leaves to silking, respectively. SUNDERMAN et al. (1997) also found greater increases in reading values in early vegetative stages (six to seven and 10 to 11 expanded leaves) than during reproductive stages (R1 and R6), with values of 0.58 and 0.10 units day ${ }^{-1}$, respectively. These results indicate that mistakes in the assessment of maize nitrogen status caused by variability in the SPAD reading values are more likely to happen in early than in late stages of maize development.

Monitoring maize $\mathrm{N}$ level using a chlorophyll portable meter is an easy and handy method for growers. This alternative allows to make field diagnosis of the plant nitrogen status quickly, providing important information for future management decisions. When reading values are higher than the correspondent adequate level at any particular growth stage, nitrogen should not be applied since the plant is not in need of the nutrient at that moment. Conversely, when values are below the 
desired level, it is likely that maize will have a positive response to supplemental $\mathrm{N}$ application. The method has the limitation of not predicting the amount of nitrogen that has to be applied. The correct determination of nitrogen rate will depend on several factors, such as crop stage, type and amount of residues of the previous crop, soil tillage method, climatic conditions, response to $\mathrm{N}$ application in previous years and target grain yield.

Grain yield potential is a point that deserves special consideration. The method presented in the current paper was aimed to obtain SPAD reading in highly productive environments. The reported reading values will probably not be accurate for low yield producing systems.

\section{CONCLUSIONS}

Portable chlorophyll readings above 45.4 , $52.1,55.3$ and 58.0 at the stages of three to four, six to seven, 10 to 11 fully expanded leaves and at silking, respectively, are proposed as adequate to achieve high grain yield. Portable chlorophyll meter readings are more susceptible to errors during maize early growth stages.

\section{REFERENCES}

AL-ABBAS, A.H. et al. Spectra of normal and nutrientdeficient maize leaves. Agronomy Journal, Madison, v.66, p.16-20, 1974.

ARGEnTA, G. Monitoramento do nível de nitrogênio na planta como indicador da adubação nitrogenada em milho. 2001. 111f. Tese (Doutorado em Fitotecnia) - Curso de Pós-graduação em Fitotecnia, Universidade Federal do Rio Grande do Sul.

ARGENTA, G.; SILVA, P.R.F. DA; BORTOLINI C.G. Teor de clorofila na folha como indicador do nível de $\mathrm{N}$ em cereais. Ciência Rural, Santa Maria, v.31, p.715-722, 2001 a.

ARGENTA, G. et al. Parâmetros indicadores do nível de nitrogênio na cultura do milho. Pesquisa Agropecuária Brasileira, Brasília, v.37, p.519-527, 2001 b.

ARGENTA, G. et al. Relação da leitura do clorofilômetro com os teores de clorofila extraível e de nitrogênio na folha de milho. Revista Brasileira de Fisiologia Vegetal, São Carlos, v.13, p.158-167, 2001c.

ARGENTA, G. et al. Adubação nitrogenada em milho pelo monitoramento do nível de nitrogênio na planta por meio do clorofilômetro. Revista Brasileira de Ciência do Solo, Viçosa, v.27, p.109-119, 2003.

BINFORD, G.D.; BLACKMER, A.M.; MEESE, B.G. Optimal concentrations of nitrate in cornstalks at maturity. Agronomy
Journal, Madison, v.84, p.881-887, 1992.

BLACKMER, T.M.; SCHEPERS, J.S. Use of chorophyll meter to monitor nitrogen status and schedule fertigation for corn. Journal of Production Agriculture, Madison, v.8, p.56$60,1995$.

BULLOCK, D.G.; ANDERSON, D.S. Evaluation of the minolta SPAD 502 chlorophyll meter for nitrogen management in corn. Journal of Plant Nutrition, New York, v.21, p.741755,1998 .

CATE, R.B.; NELSON, L.A. A simple statistical procedure for partitioning soil test correlation data into two classes. Soil Science Society of American Proceedings, Madison, v.35, p.658-660, 1987.

DWYER, L.M. et al. Quantifying the nonlinearity in chlorophyll meter response to corn leaf nitrogen concentration. Canadian Journal of Plant Science, Ottawa, v.75, p.179-182, 1995.

EARLEY E.B.; MCIIRATH W.O.; SEIF R.D. Effects of shade applied at different stages of plant development on corn (Zea mays L.) production. Crop Science, Madison, v.7, p.151156, 1967.

EMBRAPA. Centro Nacional de Pesquisa de Solos. Sistema brasileiro de classificação de solos. Brasília : EMBRAPA, 1999. 412p.

FOX, R.H. et al. Soil and tissue nitrate tests compared for predicting soil nitrogen availability to corn. Agronomy Journal, Madison, v.81, p.971-974, 1989.

HANWAY, J.J. Growth stages of corn (Zea mays L.). Agronomy Journal, Madison, v.55, p.487-491, 1963.

HASHEMI-DEZFOULI, A.; HERBERT, S.J. Intensifying plant density response of corn with artificial shade. Agronomy Journal, Madison, v.84, p.547-551, 1992.

HONG, S.D.; FOX, R.H.; PIEKIELEK, W.P. Field evaluation of several chemical indexes of soil nitrogen availability. Plant Soil, Netherlands, v.123, p.83-88, 1990.

IPAGRO. Seção de Ecologia Agrícola. Atlas agroclimático do Estado do Rio Grande do Sul. Porto Alegre, 1989. 210 p.

JEMISON, J.M.; LYTLE, D.E. Field evaluation of two nitrogen testing methods in maize. Journal of Production Agriculture, Madison, v.9, p.108-113, 1996.

MAGDOFF, F.R. et al. A soil test for nitrogen availability in the northeastern United States. Communications in Soil Science and Plant Analysis, New York, v.21, p.1103-1115, 1990

MARQUARD, R.D., TIPTON, J.L. Relationship between extractable chlorophyll and an in situ method to estimate leaf greenness. HortScience, Alexandria, v.22, p.1327, 1987.

MARSCHNER, H. Mineral nutrition of higher plants. London. : Academic, 1995. 350p.

MASONI, A.; ERCOLI, L.; MARIOTTI, M. Spectral properties of leaves deficient in iron, sulfur, magnesium, and 
manganese. Agronomy Journal, Madison, v.88, p.937-943, 1996.

MAYASICH, J.M.; MAYASICH, S.A.; REBEIZ, C.A. Response of corn (Zea mays), soybean (Glycine max), and several weed species to dark-applied photodynamic herbicide modulators. Weed Science, Champaign, v.38, p.10-15, 1990

MOREno, J.A. Clima do Rio Grande do Sul. Porto Alegre, 1961. 41p.

PIEKIELEK, W.P.; FOX, R.H. Use of a chlorophyll meter to predict side-dress nitrogen requirements for maize. Agronomy Journal, Madison, v.84, p.59-65, 1992.

PIEKIELEK, W.P. et al. Use of a chlorophyll meter at the early dent stage of corn to evaluate nitrogen sufficiency. Agronomy Journal, Madison, v.87, p.403-408, 1995.

SAlisBURY, F.B.; ROSS, C.W. Plant physiology. 4.ed. Belmont : Wadsworth, 1992. 685p.

SAS INSTITUTE, SAS/STAT user's guide. 4.ed. Cary NC, 1992.

SCHEPERS, J.S. et al. Comparison of corn leaf nitrogen concentration and chlorophyll meter readings. Communication in Soil Science and Plant Analysis, New York, v.23, p.2173-2187, 1992.

SCHREIBER, H.A.; STANBERRY, C.O.; TUCKER, H. Irrigation and nitrogen effects on sweet corn row number at various growth stages. Science, Washington, v.135, p.135136, 1988.

SIMS, J.T. et al. Evaluation of soil and plant nitrogen tests for maize on manured soils of the Atlantic coast plain. Agronomy Journal, Madison, v.87, p.213-222, 1995.

SMEAL, D.; ZHANG, H. Chlorophyll meter evaluation for nitrogen management in corn. Communications in Soil Science and Plant Analysis, New York, v.25, p.1495-1503, 1994.

THOMAS, H.; STODDART, J.L. Leaf senescence. Annual Review Plant Physiology, Palo Alto, v.31, p.83-111, 1980.

VARVEL, G.E.; SCHEPERS, J.S.; FRANCIS, D.D. Ability for in-season correction of nitrogen deficiency in corn using chlorophyll meters. Soil Science Society of American Journal, Madison, v.61, p.1233-1239, 1997.

WASKOM, R.M. et al. Monitoring nitrogen status of corn with a portable chlorophyll meter. Communications in Soil Science and Plant Analysis, New York, v.27, p.545-560, 1996.

WOOD, C.W. et al. Field chlorophyll measurements for evaluation of corn nitrogen status. Journal of Plant Nutrition, New York, v.15, p.487-500, 1992.

YADAVA, U.L. A rapid and nondestrutive method to determine chlorophyll in intact leaves. HortScience, Alexandria, v.21, p.1449-1450, 1986. 